\title{
FLOW INJECTION ANALYSIS (FIA) TECHNIQUES FOR THE DETERMINATION OF INORGANICS IN MOLECULAR AND ATOMIC SPECTROMETRY
}

\author{
T. Prasada Rao", N.M. Sita and C.S.P. lyer \\ Regional Research Laboratory (CSIR) \\ Trivandrum - 695019, India
}

CONTENTS

Page

1. INTRODUCTION ................................................................. 157

2. APPLICATION TO FLOW INJECTION ANALYSIS OF INORGANICS

A. Determination of Cations …............................................. 159

B. Determination of Anions .................................................. 178

C. Determination of Multielement Cations ................................... 179

D. Determination of Multielement Anions …............................ 180

3. CONCLUSIONS …............................................................ 180

4. REFERENCES …............................................................. 181

\section{INTRODUCTION}

Flow injection belongs to a family of methods, based on simple injection into a flowing stream, which carries the analyte through a chemical modulator into a detector $/ 1 /$. This broad spectrum of methods includes flow injection (FI) or flow injection analysis (FIA), chromatography, electrophoresis and field flow fractionation. These techniques differ in the function of the chemical modulator, which alters original square wave input, provided by sample injection into a fiagram, chromatogram, electrophoretogram or

\footnotetext{
- Address for correspondence:

Fax: 0091-0471-491712, 490186; E-mail: rao@csrrltrd.ren.nic.in
} 
fractogram respectively. Whereas chromatographic techniques aim at a high resolution obtained through mega repetitive interactions which modulate the migration velocities of analytes through the system, flow injection exploits chemical reactions to transform analytes into species that can be selectively modified by a detector. Although FI is the youngest of the flow based techniques $/ 2 /$, its applications have encompassed a full range of reagent assays from inorganic to enzymatic, from ions to proteins and from traces to highly concentrated analytes in aqueous or non-aqueous media.

Since its introduction, interest has been sustained in the use of FIA techniques due to the development of automated, online sample pretreatment procedures $/ 3,4 /$. The advantages of preconcentration FIA techniques include high efficiency, simple online operation, low sample reagent consumption, relatively simple and compact hardware and freedom from contamination. FIA techniques offer improvement in efficiency and in automation of different separation and preconcentration processes $15 /$. Pretreatment steps performed using FIA are rapid and require less than $1 \mathrm{~min}$ for pretreatment and analysis including chemical conversions $/ 6 /$. More interesting is the use of FIA to implement online derivatization reactions $/ 7 /$, separation processes $18,9 /$, as well as a number of sample handling modes to fit the initial sample conditions and the most suitable single- and multidetection /10-12/ or implementation of flow through (bio)chemical sensors /13-15/ among others.

The growing interest in the use of FIA techniques was demonstrated in several reviews $/ 16-26 /$ and in a recent book $/ 27 \%$. This article intends to provide an overview on the determination of inorganics by FIA described in literature since 1990. Various FIA procedures with a number of molecular and atomic spectrometric detection techniques for the determination of inorganics are classified into four types viz. (a) cations, (b) anions, (c) multielement cations, (d) multielement anions. The salient features of these procedures are summarized in Tables $1-4$ respectively. 


\section{APPLICATION TO FLOW INJECTION ANALYSIS OF INORGANICS}

\section{A. Determination of Cations \\ (a) UV-Vis spectrophotometry}

FI-spectrophotometric procedures were described for the analysis of silver in mineral standards $/ 29 /$, ammonium ion in sea water $/ 77 /, \mathrm{pH}$ in lake water $/ 66 /$, aluminum in tap water, tea leaves and flour $/ 30 /$, cobalt in tobacco leaves and pyrite ore reference materials /45/. Further, cobalt 143/, molybdenum $/ 75 /$, tin $/ 110 /$ and titanium $/ 116 /$ in steels, titanium in bauxite $/ 115 /$ and uranium in standard ores $/ 118 /$ were determined by FI spectrophotometry. A few FI-spectrometric procedures were developed for the sensitive determination of copper in water and plants $/ 4$, rock samples $152 /$, $\mathrm{Al}$ alloys $/ 55 /$, natural waters $/ 56 /, \mathrm{Cu}$ based alloys and pig foods $/ 57 /$, and palladium in anode slime and sludges $198,99 /$, metallurgical samples $/ 101 /$ and ores $/ 104 /$.

\section{(b) Flame $A A S$}

Fl-flame AAS procedures were described for the sensitive determination of copper in potable water /53/ and bovine serum /54/ and lead in various waters $/ 97 /$. FI-hydride generation AAS procedures were developed for the trace determination of tin in low alloy steels $/ 111 /$ and lead in various water samples $195 /$. Mercury in zinc battery anodes and water samples $/ 70 /$ was determined by cold vapour FI-AAS.

\section{(c) $G F-A A S$}

Sensitive FI-GF-AAS procedures were described (i) directly for the determination of lead in standard reference materials of sea and river water $185 /$, biological tissues and natural waters $/ 91$, (ii) via hydride generation for the determination of tin in steel, sediment, orchard leaves and bovine liver $/ 112 /$ and germanium in soil and Chinese herbal drugs $/ 64 /$ and (iii) by carbonyl vaporization for the determination of nickel in water and grass $/ 81$.

\section{(d) ICP-MS}

A Fl-ICPMS procedure for the determination of lead in undiluted urines and standard reference urine samples $/ 92 /$ was described during this period. 
Vol. XVIII, No. 3 Flow Injection Analysis (FIA) Techniques for the Determination of Inorganics in Molecular and Atomic Spectrometry

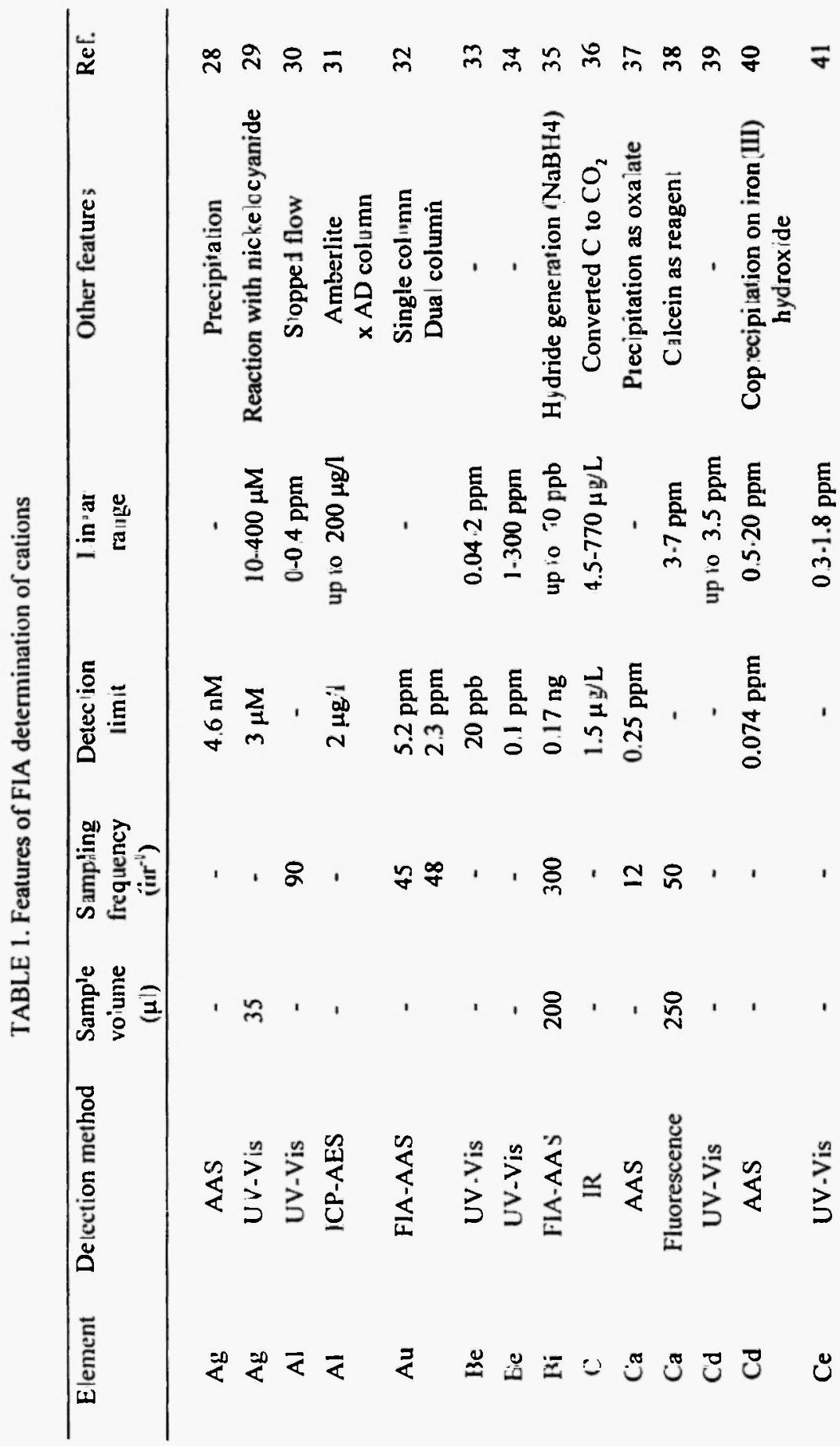




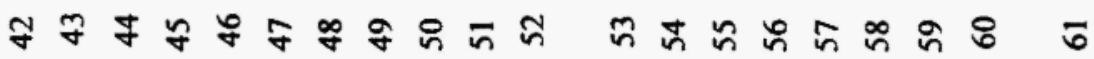

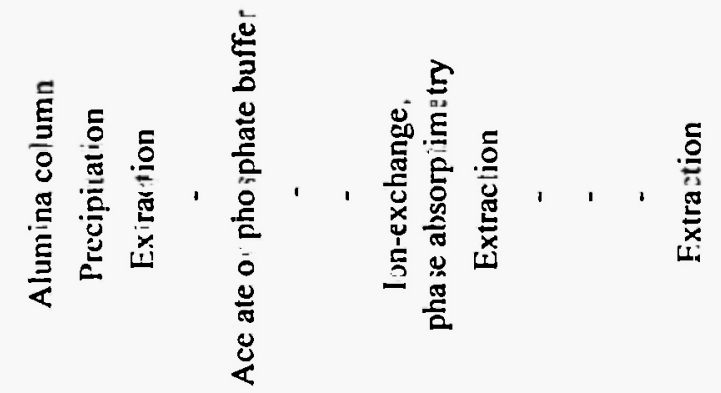

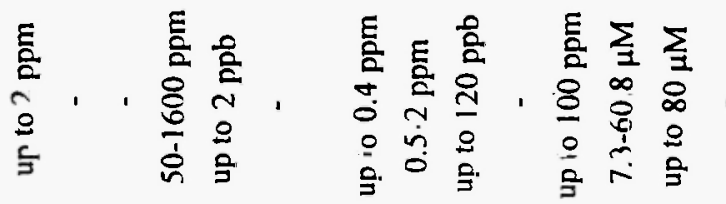

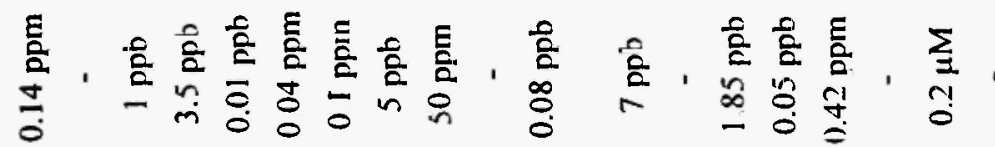

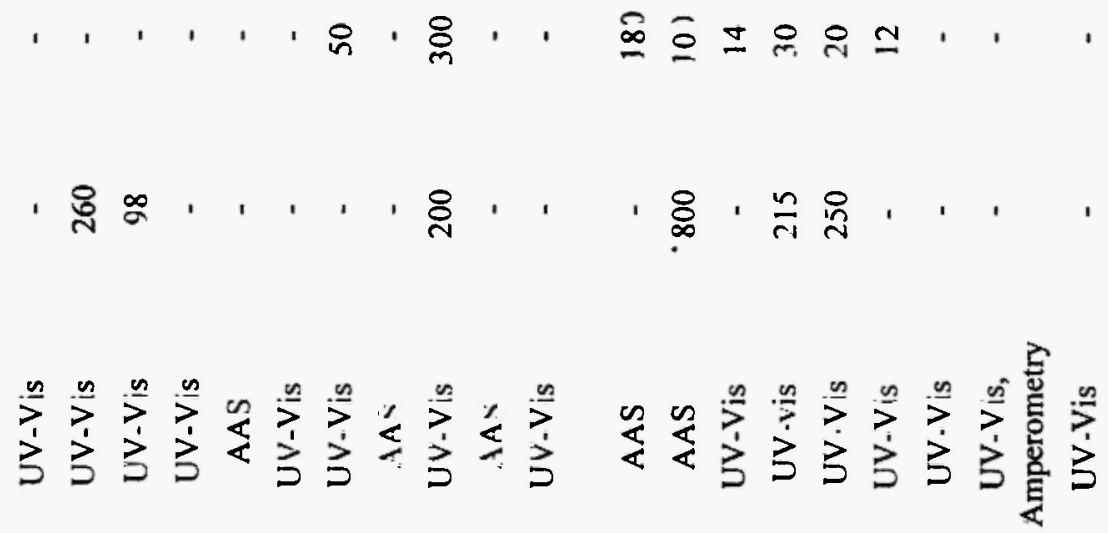

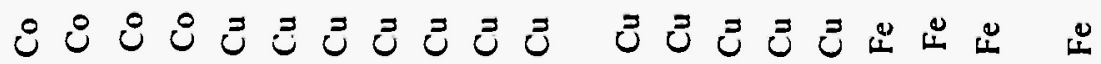




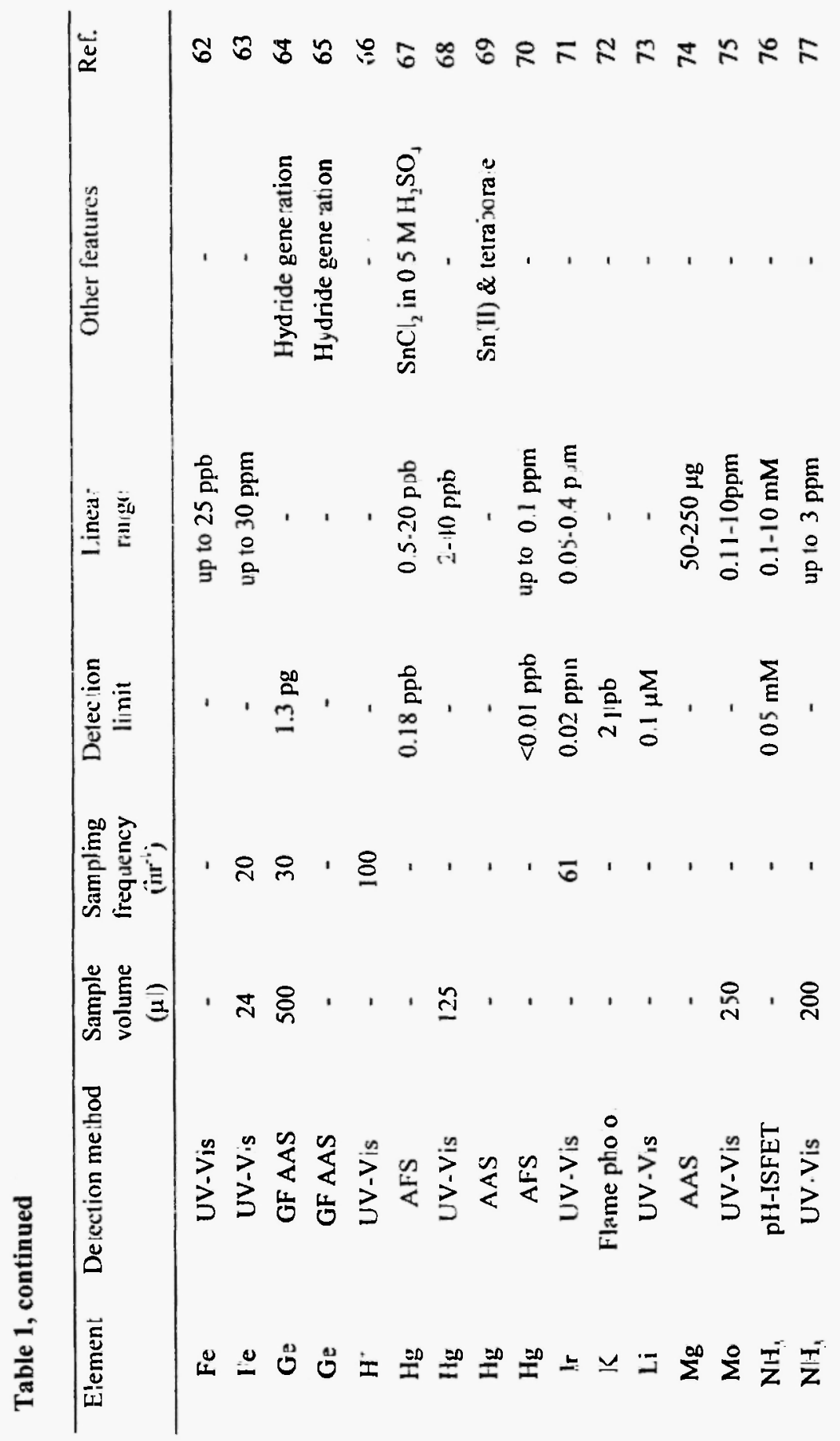




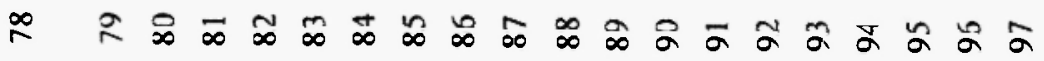

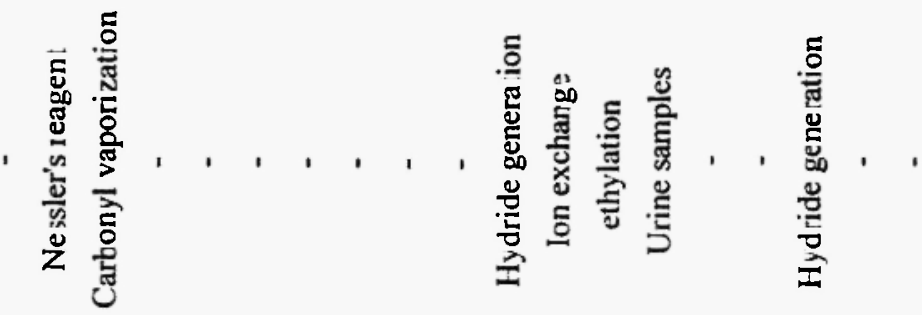

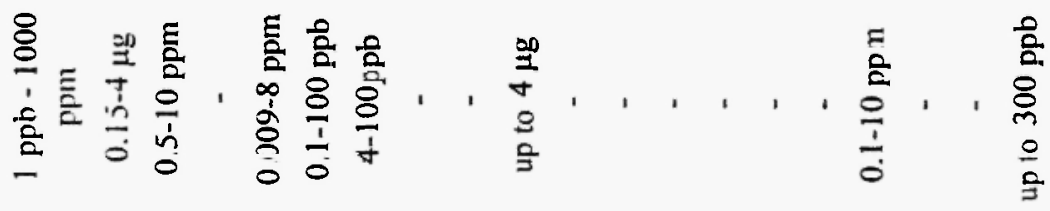

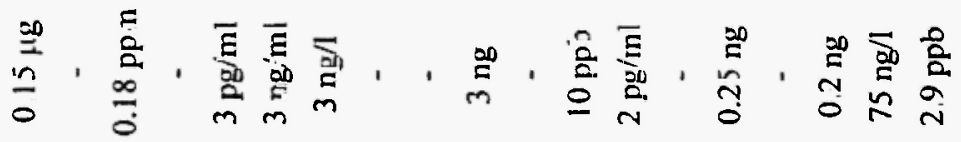

, ', ', ', ', $8808,1,1,1,1$,

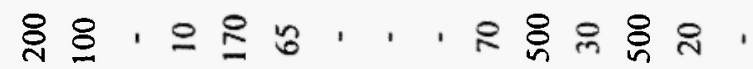

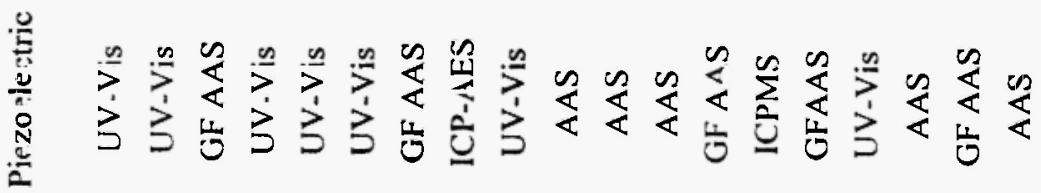

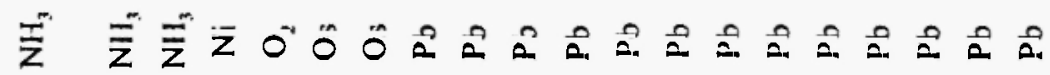



of Inorganics in Molecular and Atomic Spectrometry

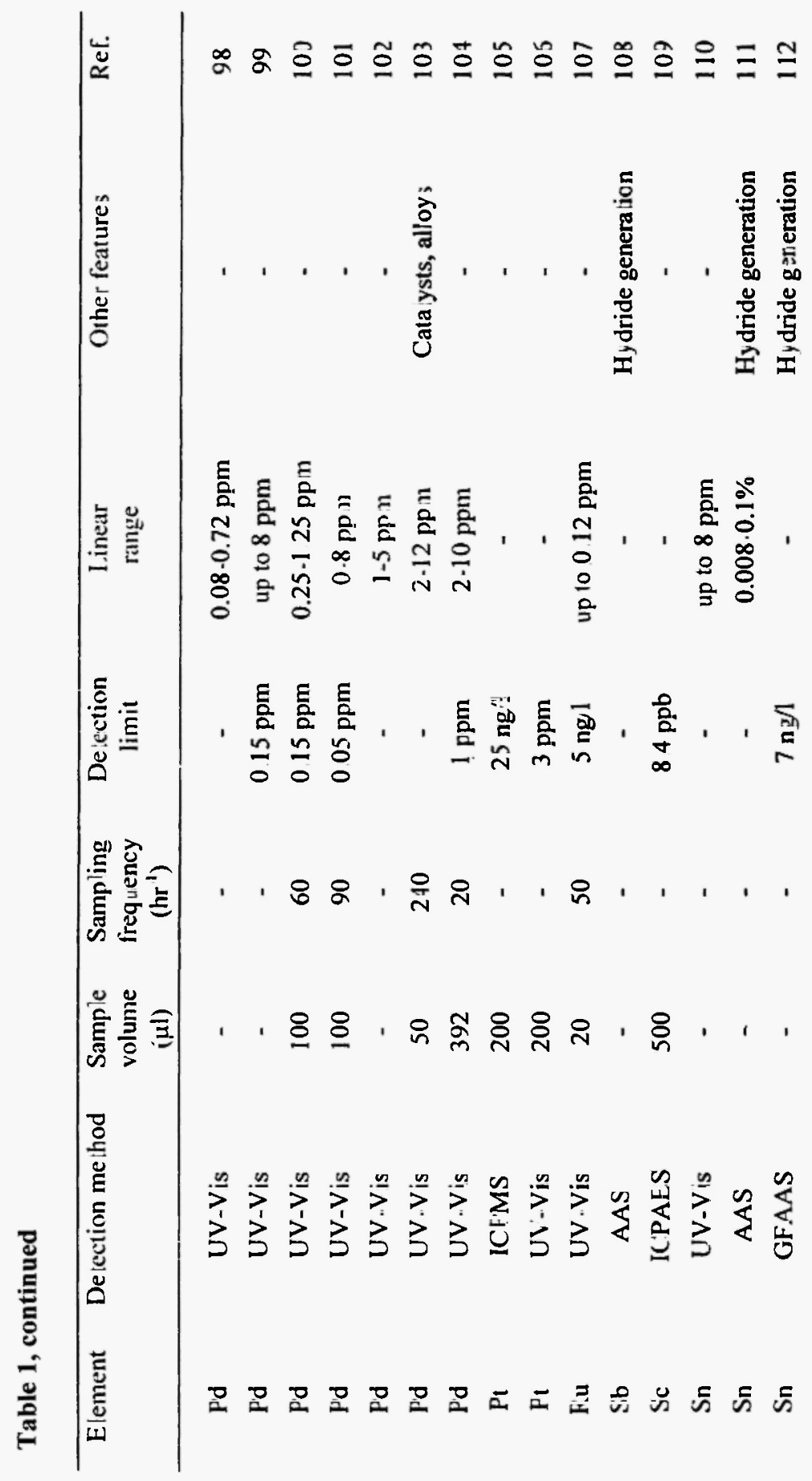




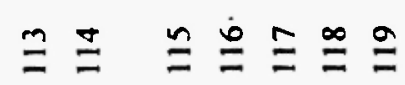

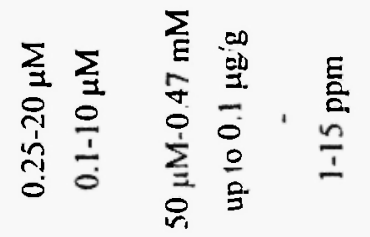

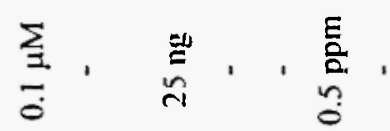

, , 8,8,

유, ,

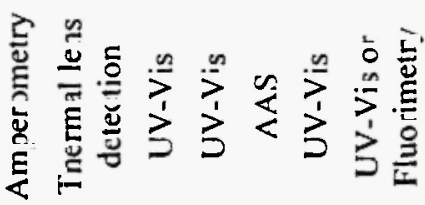

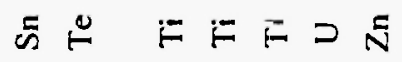


Vol. XVIII, No. 3 Flow Injection Analysis (FIA) Techniques for the Determination of Inorganics in Molecular and Atomic Spectrometry

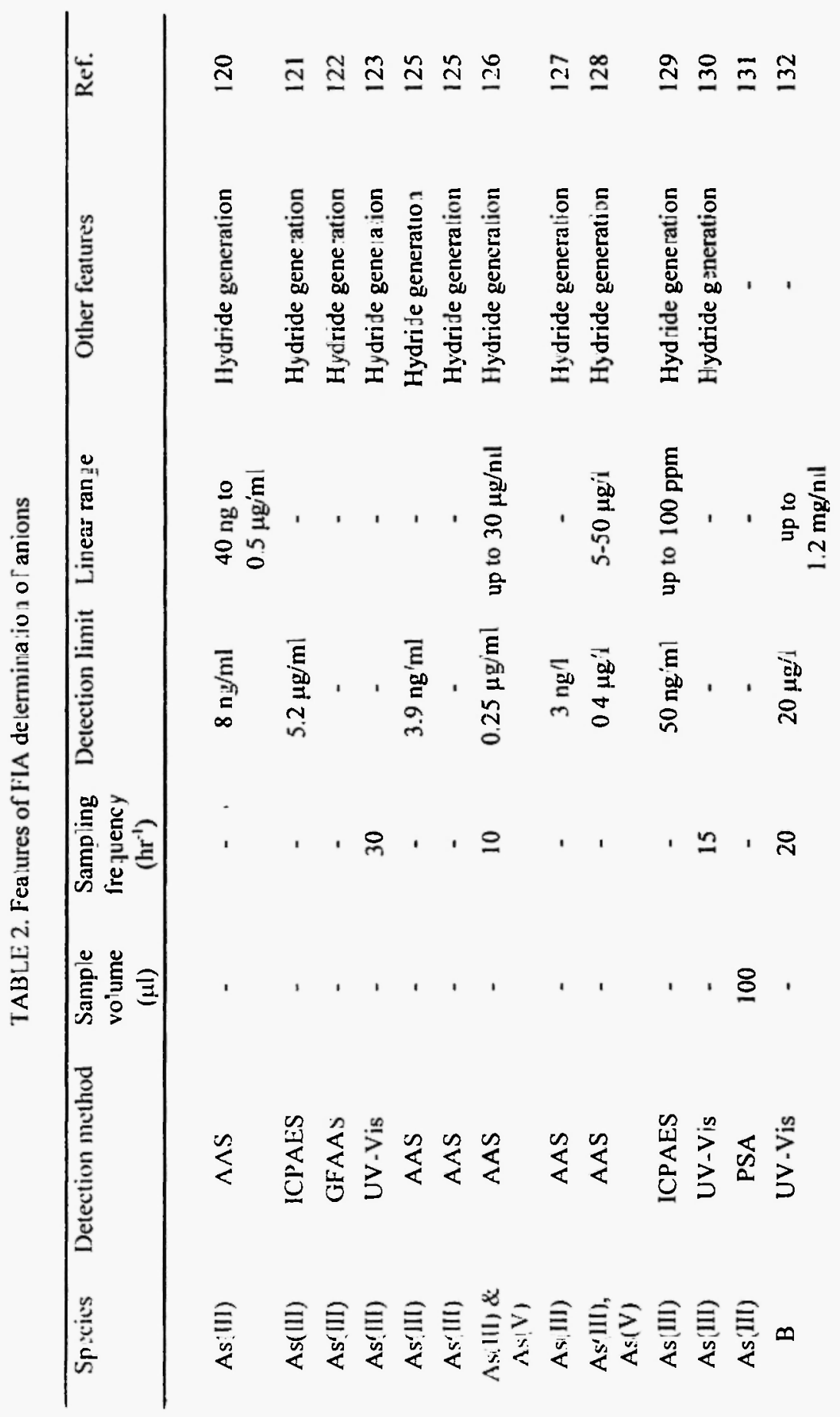




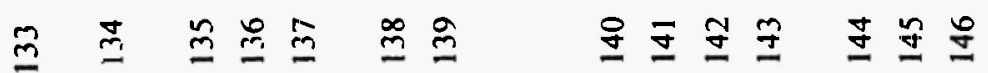

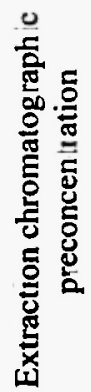

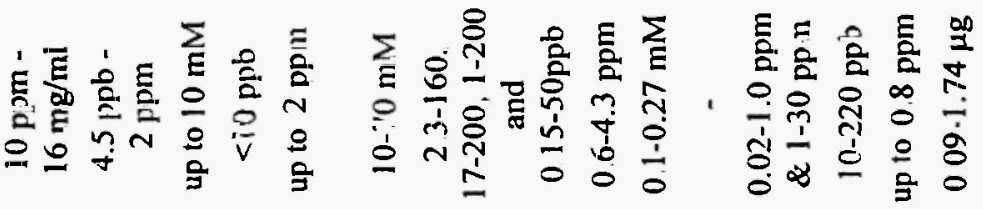

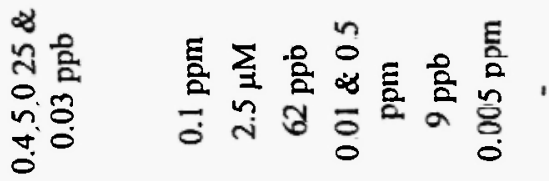

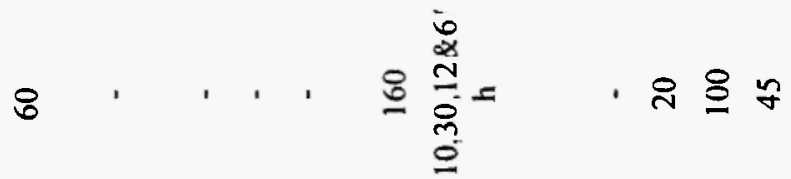

, ' '

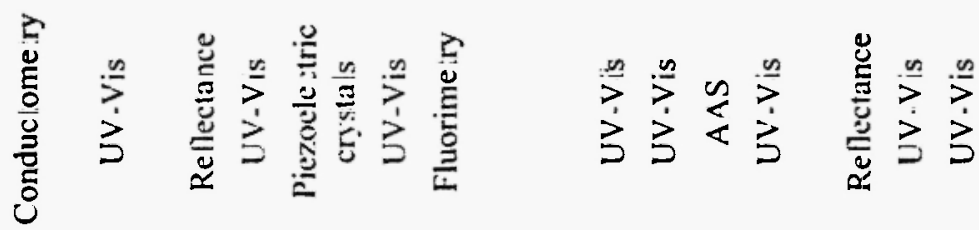

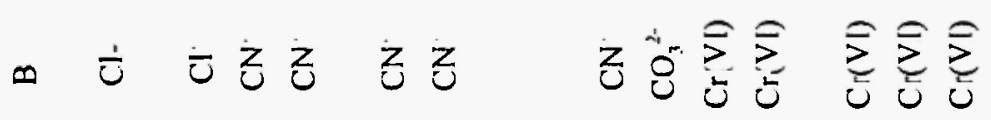


Vol. XVIII, No. 3 Flow Injection Analysis (FIA) Techniques for the Determination of Inorganics in Molecular and Atomic Spectrometry

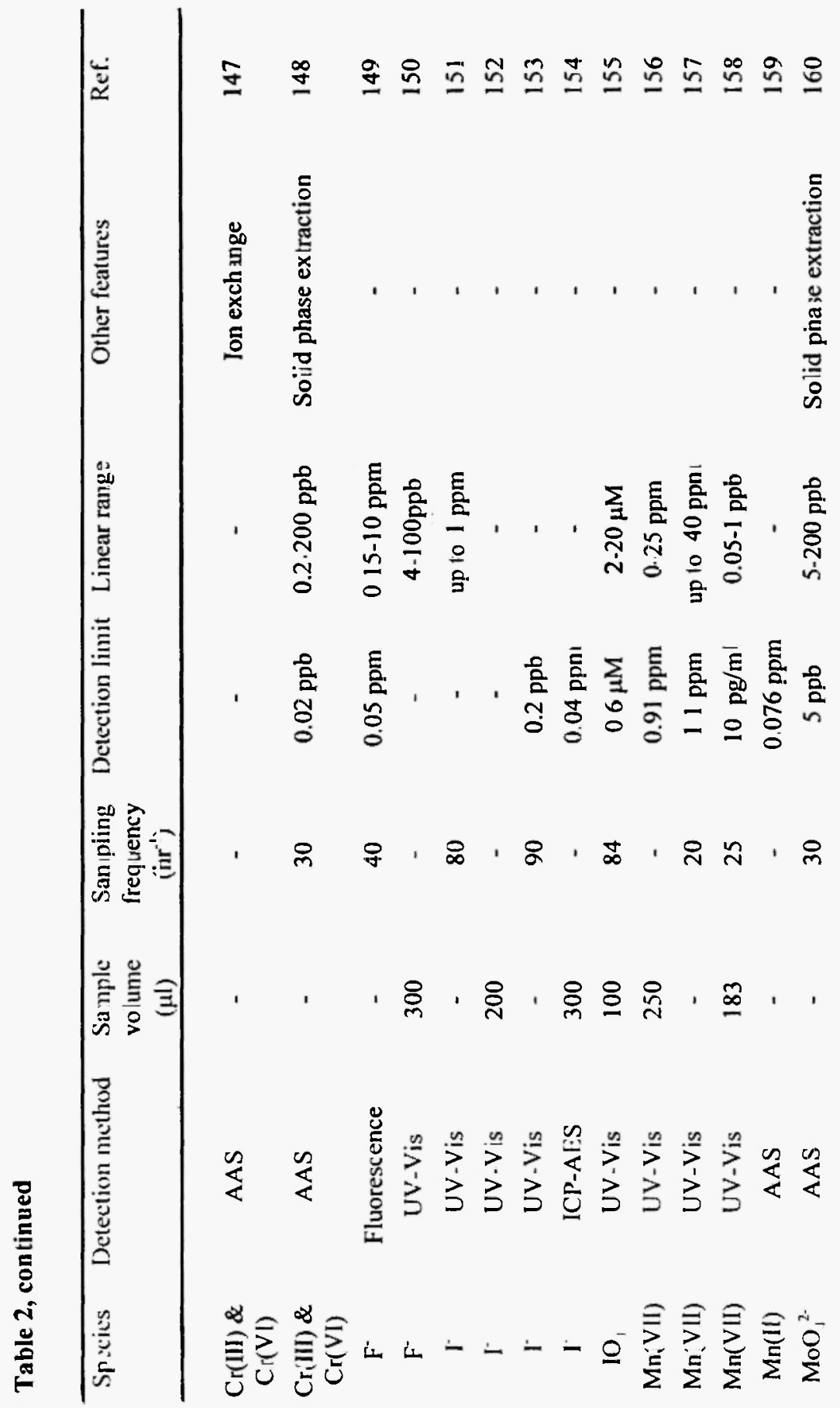




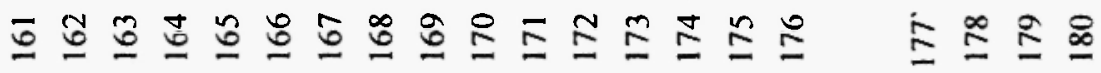

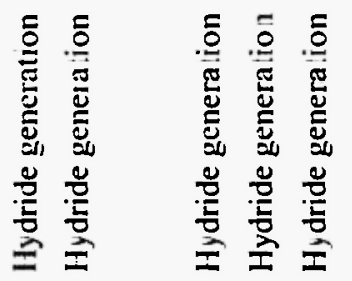

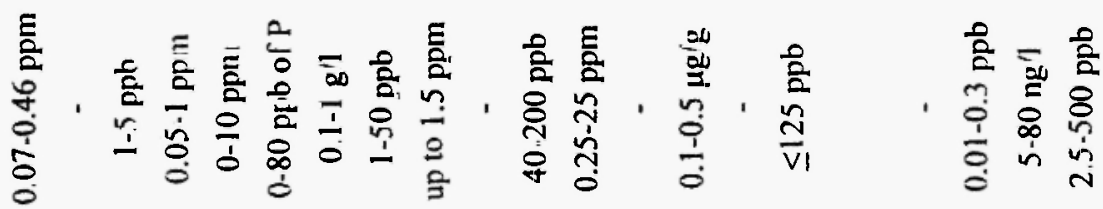

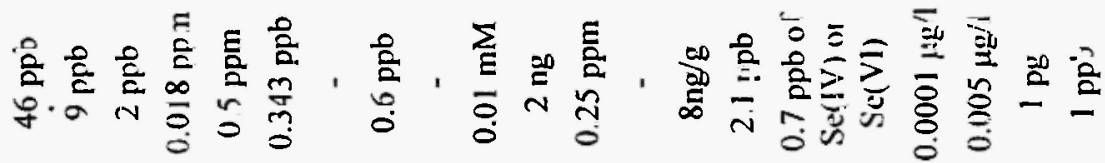

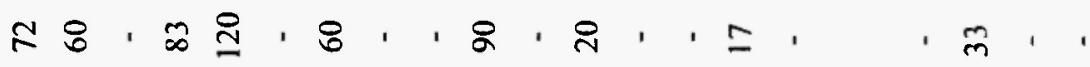

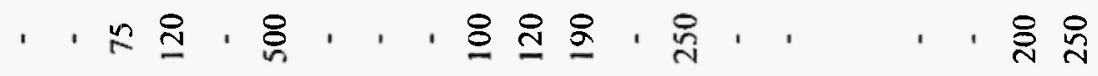

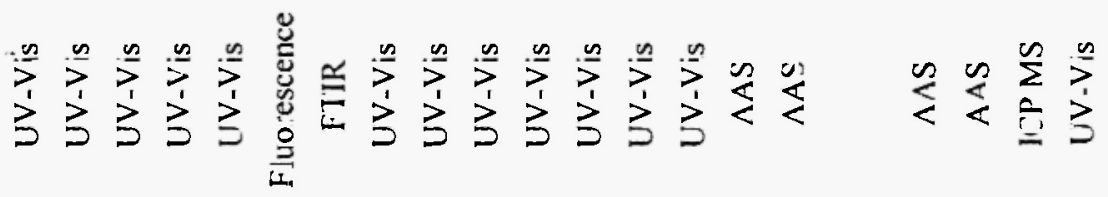

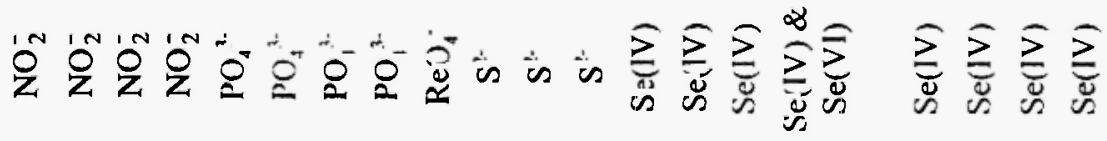


Vol. XVIII, No. 3 Flow Injection Analysis (FIA) Techniques for the Determination of Inorganics in Molecular and Atomic Spectrometry.

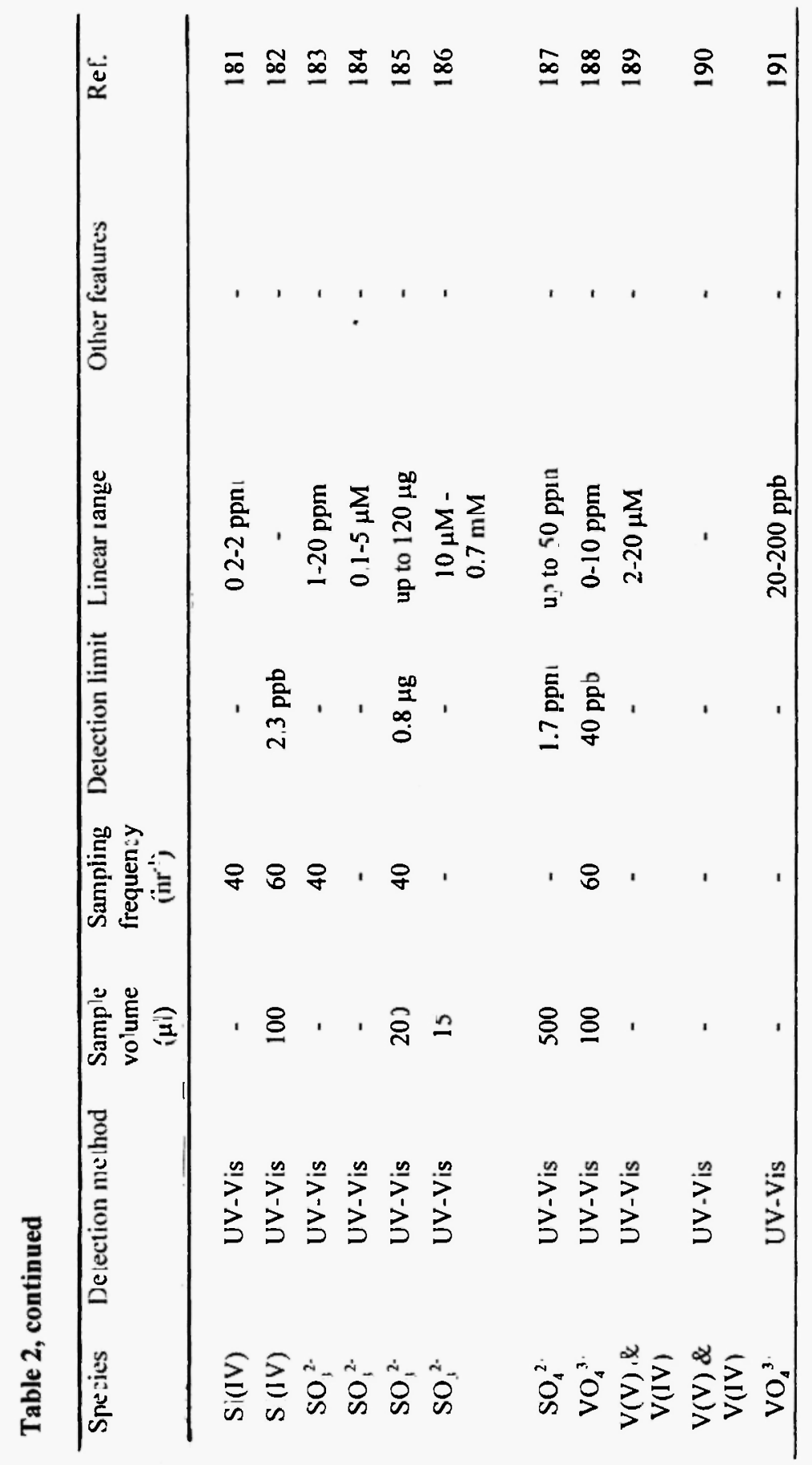




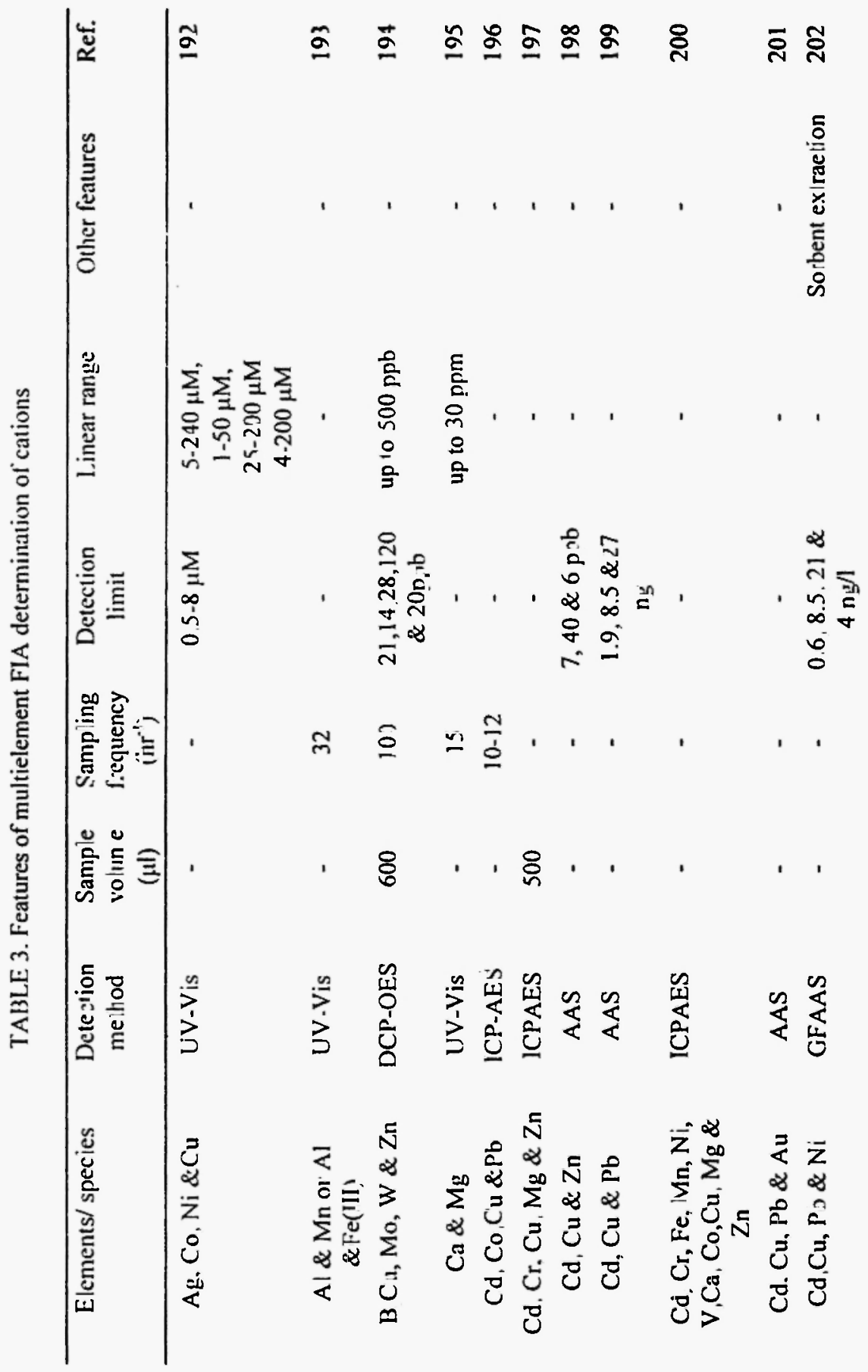


Vol. XVIII, No. 3 Flow Injection Analysis (FIA) Techniques for the Determination of Inorganics in Molecular and Atomic Spectrometry

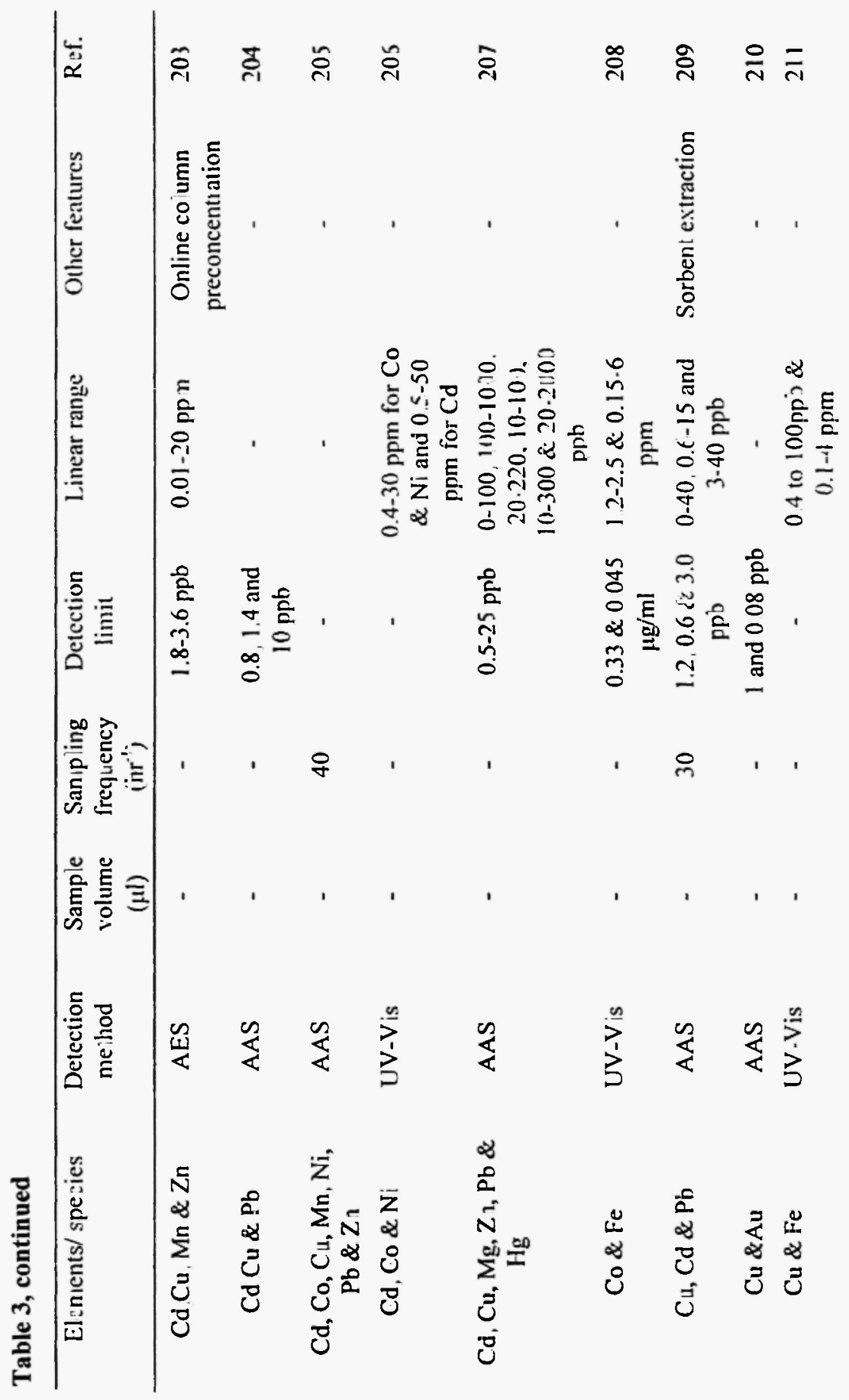




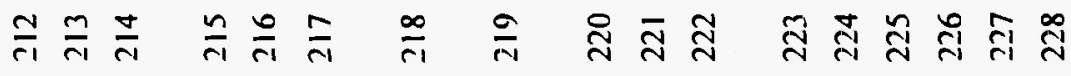

$$
\begin{aligned}
& \text {. . }
\end{aligned}
$$

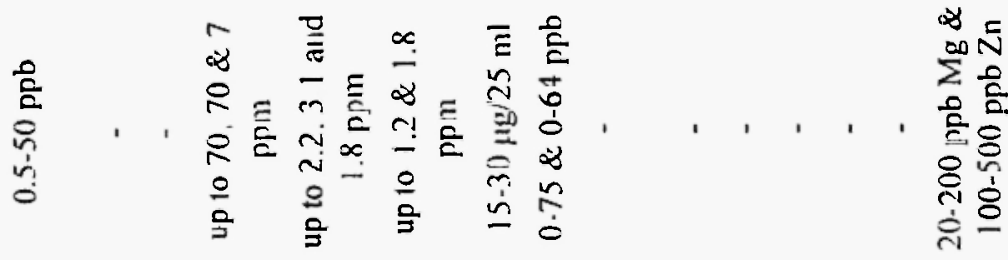

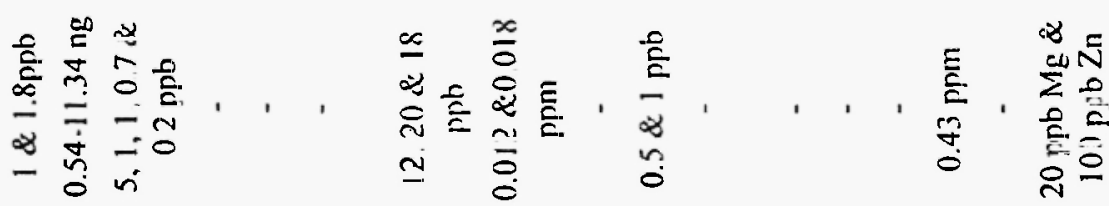

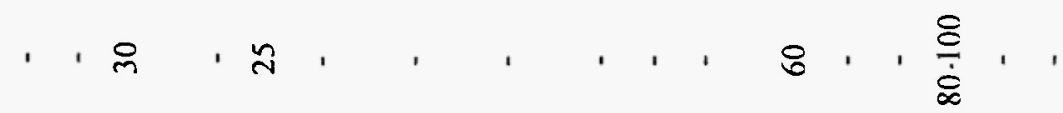

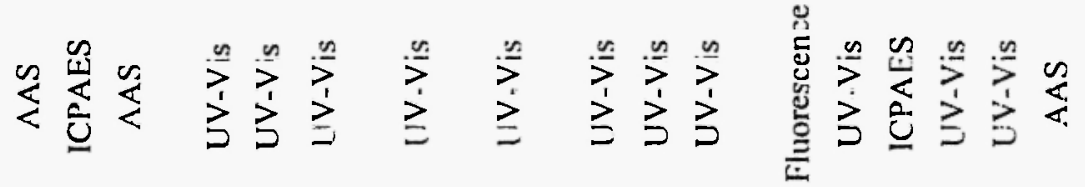

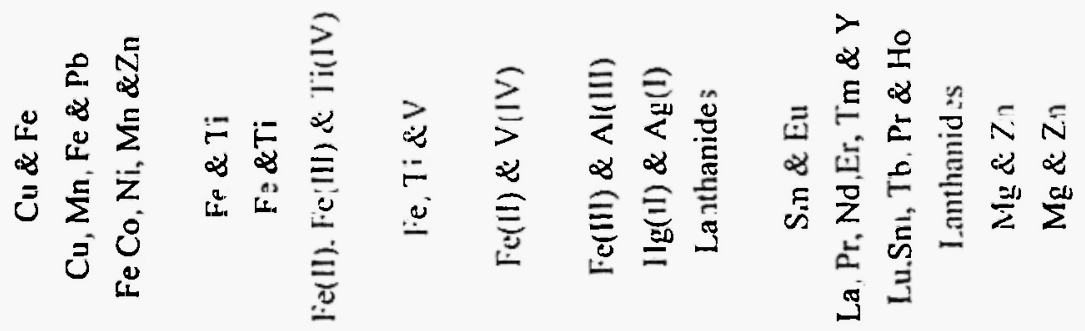




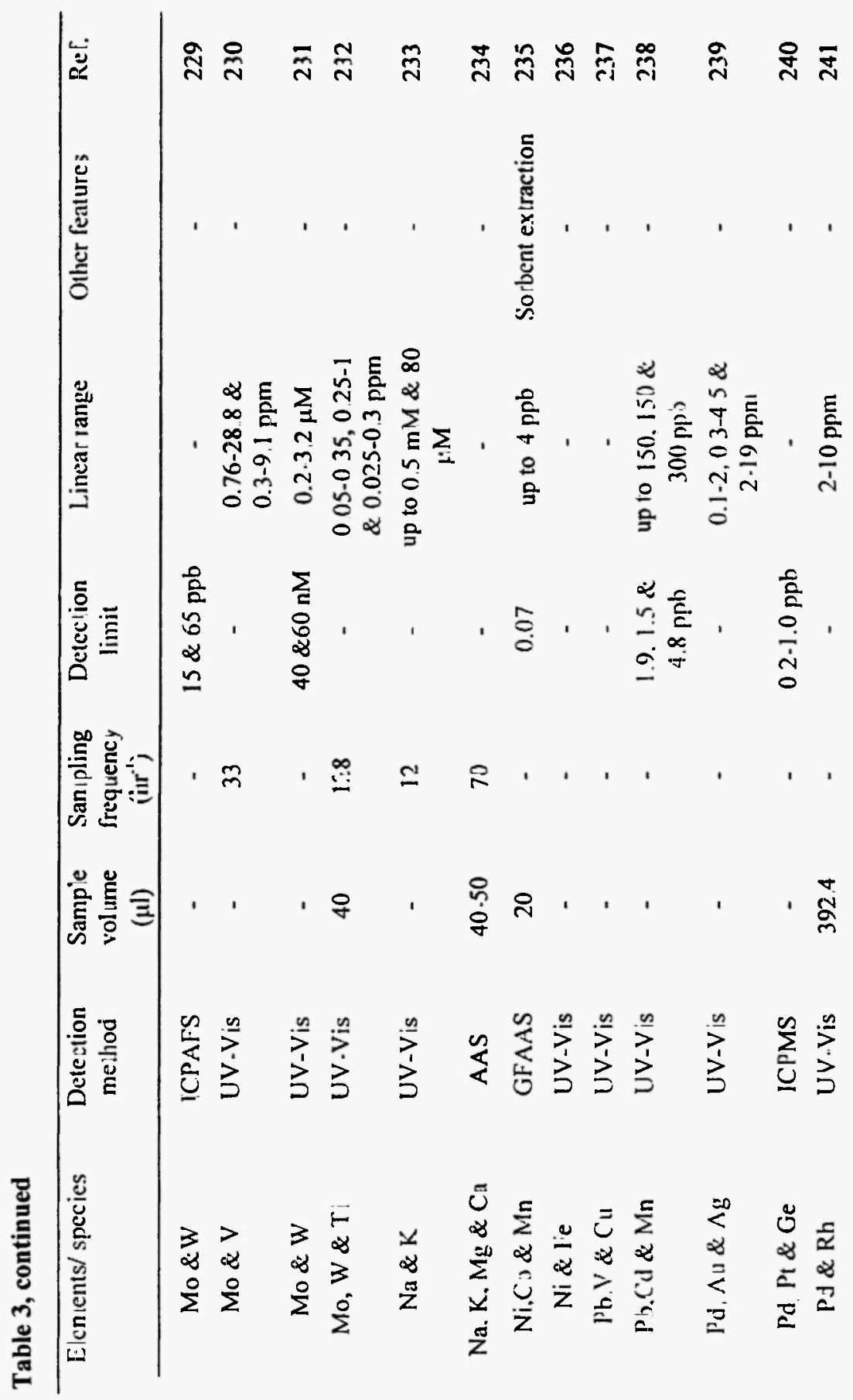




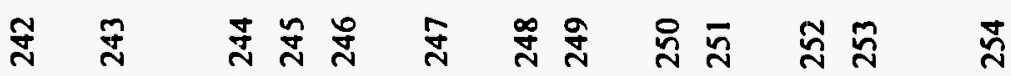
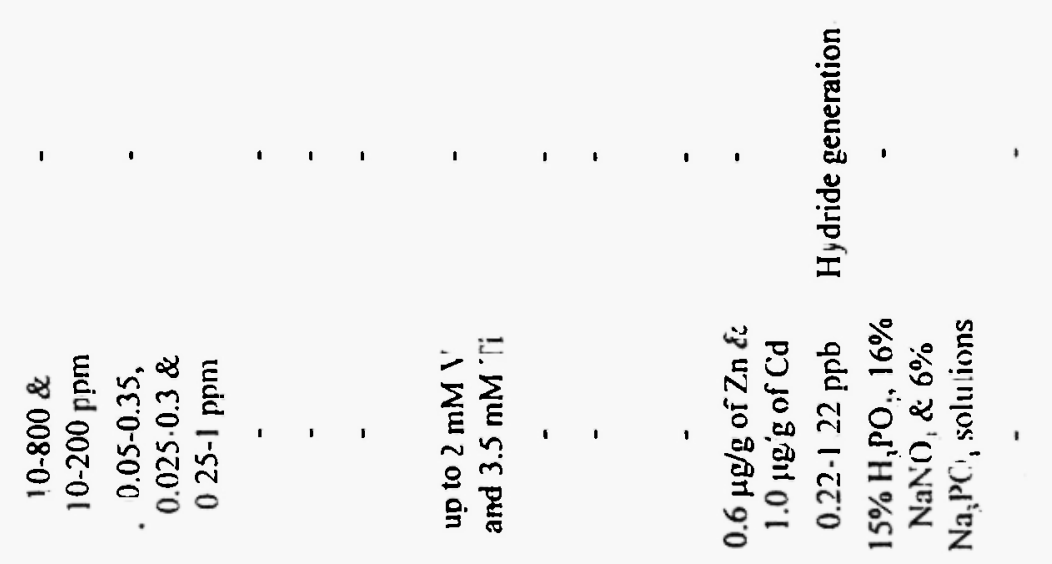

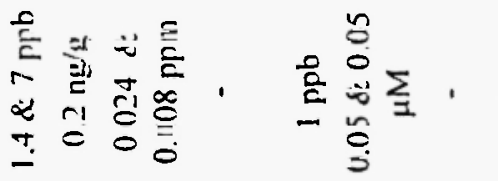

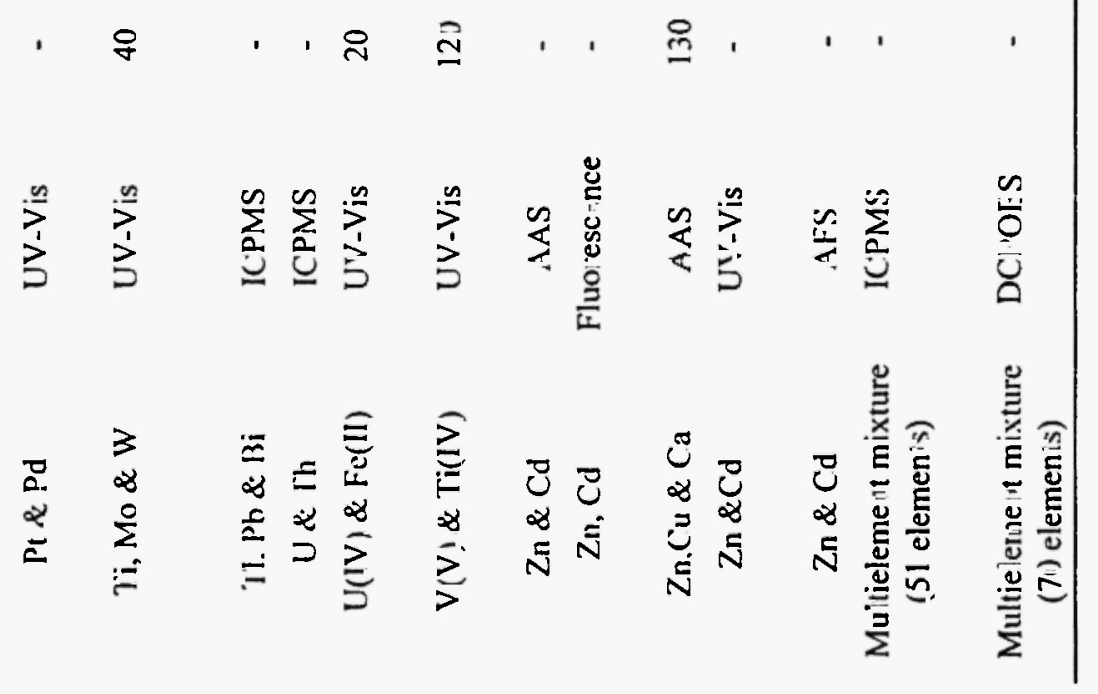


Vol. XVIII, No. 3 Flow Injection Analysis (FIA) Techniques for the Determination of Inorganics in Molecular and Atomic Spectrometry

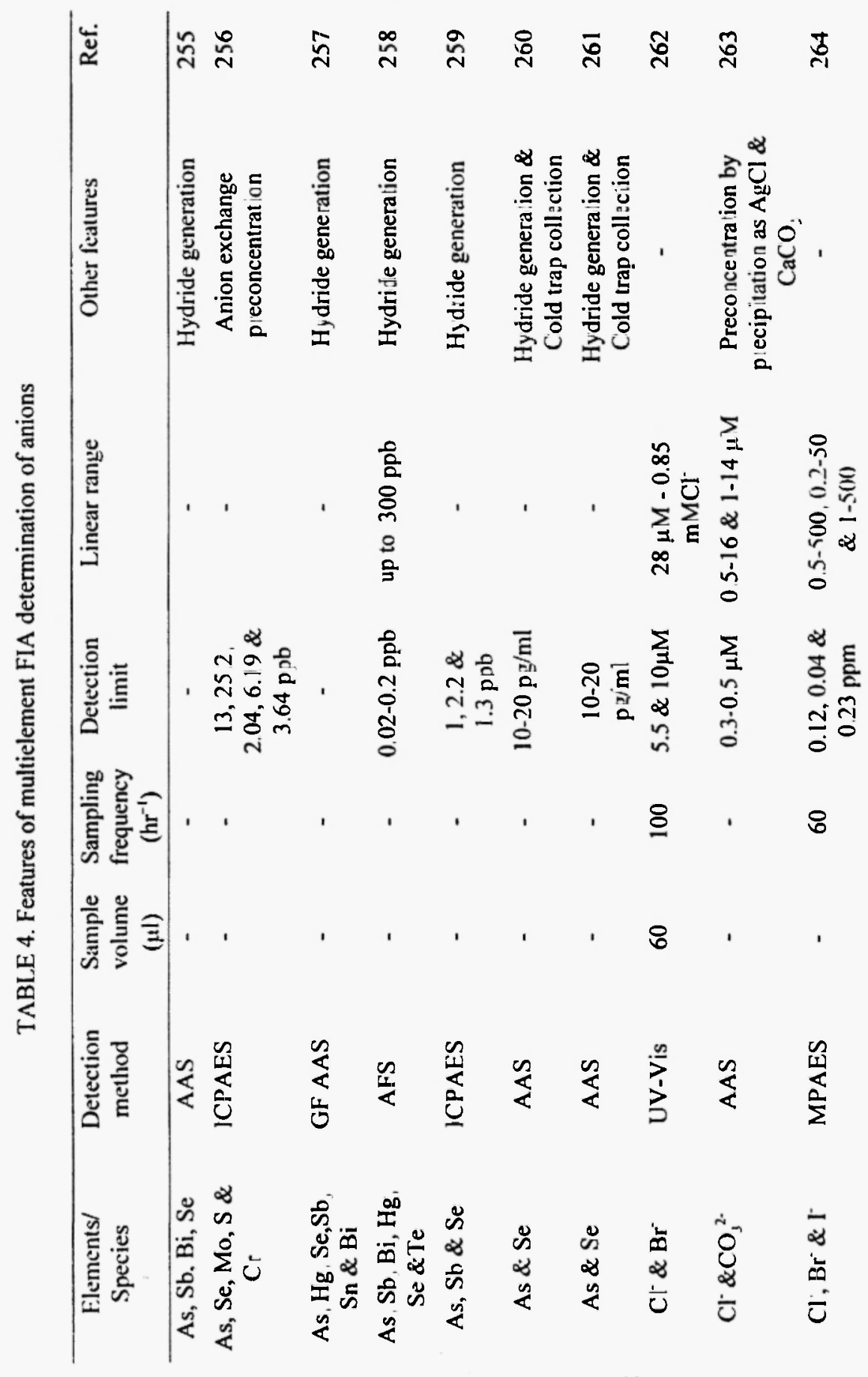




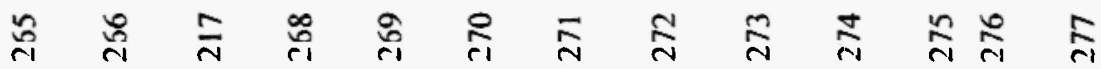

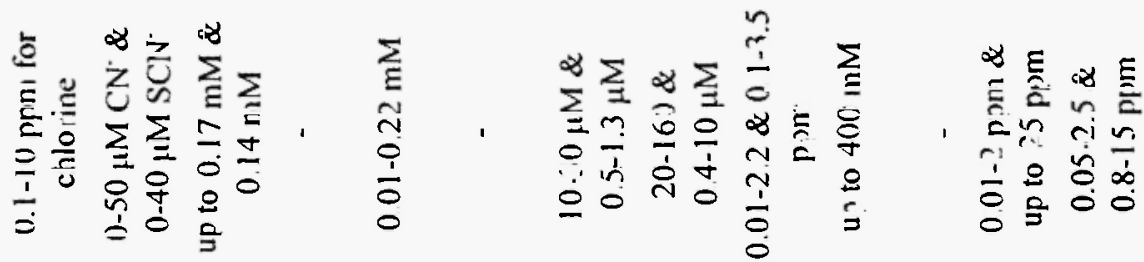

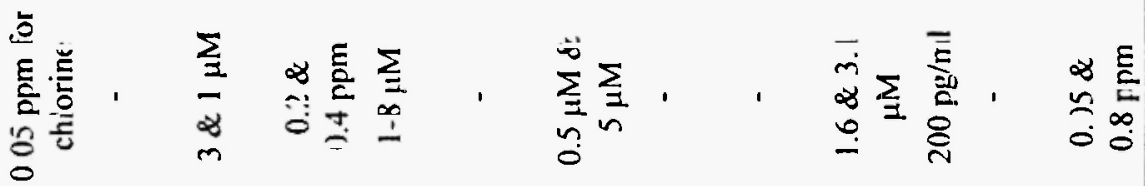

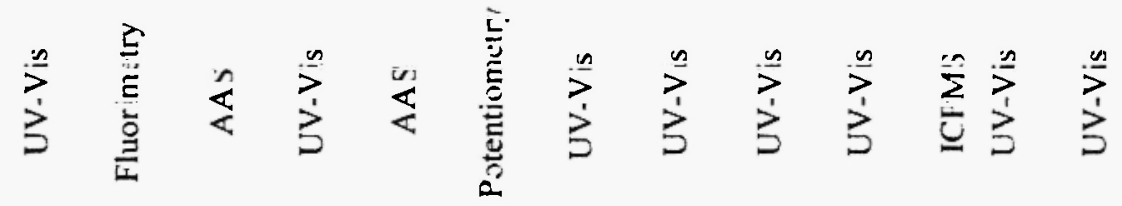

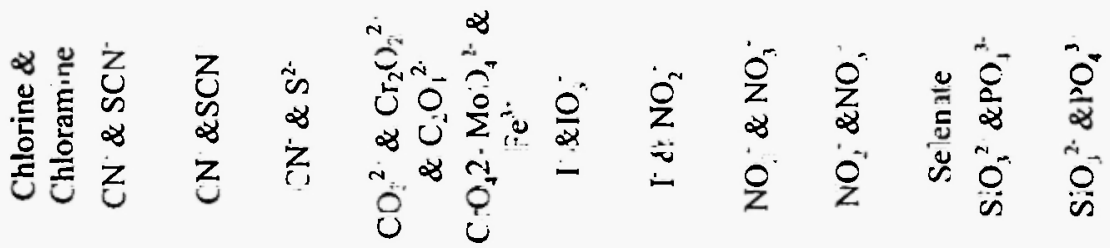




\section{(e) Miscellaneous}

Spectrofluorimetric $/ 38 /$ and $\mathrm{pH}$ ISFET /76/ detectors were used in combination with FI for the online determination of calcium and ammonia respectively.

\section{B. Determination of Anions}

\section{(a) UV-Visible spectrophotometry}

FI-UV-Vis spectrophotometric procedures were developed for the determination of cyanide $/ 136,140 /$, chromium $/ 145,143 /$, fluoride $/ 149 /$, manganese $/ 157 /$, nitrite $/ 161,162 /$, silicate $/ 181,182 /$, sulphide $/ 171 /$, total phosphorus $/ 168 /$ in various water samples. Trace amounts of boron in eye lotion and sea water $/ 132 /$, sulphite in lemon juice $/ 185 /$, nitrite in wine $/ 159 /$, arsenic in soil /130/, selenium in lobster /173/ and hair, $\mathrm{Cu}^{2+}$ and $\mathrm{Fe}^{3+} / 174 /$, iodide in tablets, table salt and animal feed $/ 150 /$ and vanadium in peanut, rice and wheat flour /191/ were determined by using FI-spectrophotometry. Manganese in $\mathrm{Cu}, \mathrm{Ni}$ alloy /155/ and steel and alloys /156/, selenium in ores and personal care products $/ 180 /$ and cyanide in mineral leach liquors were determined by sensitive FI-spectrophotometric procedures.

\section{(b) $A A S$}

Sensitive FI-AAS procedures were developed for the determination of manganese in hair, surface water and traditional Chinese medicines /158/ and molybdenum in sea water and sediments $/ 160 \%$. Two speciative procedures were developed for the simultaneous determination of chromium(VI) and chromium(III) in various water samples and sediments $/ 148 /$ and selenium(IV) and selenium(VI) via hydride generation in sea water /176/ using a FI-AAS technique.

\section{(c) ICP-AES}

A FI-ICPAES procedure was described for the determination of iodide in cooking salt $/ 153 /$. 
(d) ICP-MS

A FI-1CPMS procedure was developed for the ultratrace determination of selenium via hydride generation in estuarine water samples $/ 179 /$.

\section{(e) Miscellaneous}

Flow injection coupled to fluorescent /148/ and FTIR /166/ detectors were described during this period for trace determination of fluoride and phosphate, which find application in their determination in river water and soft drinks respectively.

\section{Determination of Multielement Cations}

\section{(a) UV-Visible spectrophotometry}

Simultaneous FI-spectrophotometric procedures were developed for the determination of zinc and cadmium $/ 251$, calcium and magnesium /197/, cobalt and iron $/ 208 /$, copper and iron $/ 211$, sodium and potassium $/ 233 /$, mercury and silver $/ 221 /$, and iron(II) and vanadium(IV) $/ 219 /$ in various water samples. The determination of aluminum and manganese /193/ aluminum and iron /193/ and calcium and magnesium /193/ in soil extracts and sedimentary rocks, $\mathrm{Co}, \mathrm{Ni}$ and $\mathrm{Cd}$ in catalysts $/ 206 /$, molybdenum and vanadium in steels, pharmaceuticals and petroleum products 1230 , lead, cadmium and manganese in rice flour samples $/ 238 /, \mathrm{U}(\mathrm{IV})$ and $\mathrm{Fe}(\mathrm{II})$ in $\mathrm{Sc}_{2} \mathrm{O}_{3}$, phosphate ore and thorium nitrate $/ 246 /$ and $\mathrm{Mo}$ and $\mathrm{W}$ in minerals 1231/ was described by various authors, using FI-spectrophotometric techniques based on a variety of chromogenic reagents.

\section{(b) Flame $A A S$}

FI-flame AAS procedures were described for the simultaneous determination of $\mathrm{Cu}, \mathrm{Cd}$ and $\mathrm{Pb} / 209 /$ and $\mathrm{Fe}, \mathrm{Co}, \mathrm{Ni}, \mathrm{Mn}$ and $\mathrm{Zn} / 214 /$ in sea water and marine sediments, $\mathrm{Cu}, \mathrm{Cd}$ and $\mathrm{Pb}$ in urine /201/ and digests of environmental, biological and industrial materials /204/ and copper and gold in standard ores $/ 210 \%$.

(c) $G F-A A S$

A FI online sorbent extraction GF-AAS procedure was described for the determination of $\mathrm{Cu}, \mathrm{Cd}, \mathrm{Pb}$ and $\mathrm{Ni}$ in sea, estuarine and river waters /202/. 
Vol. XVIII, No. 3 Flow Injection Analysis (FIA) Techniques for the Determination of Inorganics in Molecular and Atomic Spectrometry

(d) ICP-AES

Multielement determination of rare earths in mixed rare earth samples was described by Shen et al. $/ 225 /$ by using flow injection ICPAES.

(e) ICP-MS

Flow injection coupled to ICP-MS procedures was developed for the determination of thallium, lead and bismuth in nickel based alloys /244/ and uranium and thorium in aluminum samples $/ 245 /$.

\section{Determination of Multielement Anions}

(a) UV-Vis spectrophotometry

FI-spectrophotometric procedures were described for the simultaneous determination of free chlorine and chloramine in natural and drinking water $/ 265 /$, silicate and phosphate in natural waters $/ 277 /$ and power plant water /276/ and nitrite and nitrate in atmospheric aerosol filter extracts and waste water $/ 274 /$.

(b) $A A S$

Hydride generation AAS (FI or CF) methods were described for the simultaneous determination of arsenic and selenium in environment materials /260/ and CRM's of water, liver, citrus and tomato leaf /261/.

\section{(c) ICP-AES}

An online flow injection anion exchange preconcentration and ICP-AES procedures is described for the simultaneous determination of arsenic, selenium, molybdenum, sulphur and chromium and is utilized for the analysis of standards for geological samples, hair and bovine liver $/ 256 /$.

\section{CONCLUSIONS}

Flow injection UV-visible spectrophotometry was widely used for the determination of inorganics during the last decade. However, as pointed out by us recently $/ 278$ /, only a few Fl-spectrophotometric procedures are based on ternary complex formation. The coming years should see the development 
of such procedures in addition to development of more and more FIspectrophotometric procedures for the determination of multielement cationic and anionic species.

Another technique that has attracted a great deal of attention is FI-AAS. Unfortunately, most of these procedures are applied only to various water samples. In the next few years, it is expected that FI-AAS procedures will be developed for the multielement determination of cationic and anionic species present in complex matrices.

In spite of the great potentiality of ICP-AES and ICP-MS techniques, relatively few procedures were developed for the determination of inorganics in conjunction with flow injection. The future lies in the multielement analysis of inorganic species by using flow injection - ICP-AES and ICP-MS techniques and their application to determine these species when they are present in complex matrices.

\section{REFERENCES}

1. J. Ruzicka, Anal. Chim. Acta, 261, 3 (1992).

2. J. Ruzicka and E.H. Hansen, Anal. Chim. Acta, 78, 145 (1975).

3. J. Ruzicka and E.H. Hansen, in: Flow Injection Analysis, J.D. Winefordner (Ed.), John Wiley \& Sons, New York, 1988.

4. E. Debrah, C.E. Adeeyinwo, S.R. Bysouth and J.F. Tyson, Analyst, 115, 1543 (1990).

5. G.D. Clark, D.A. Whitman, G.D. Christian and J. Ruzicka, Crit. Rev. Anal. Chem., 21, 357 (1990).

6. J. Atienza, M.A. Herrero, A. Macuqieira and R. Puchades, Crit. Rev. Anal. Chem., 23, 1 (1992).

7. T. Yamane, J. Flow Injection Anal., 8, 49 (1991).

8. M. Valcarcel and M.D. Luque de Castro, Non-Chromatographic Continuous Separation Techniques, RSC, Cambridge, 1991.

9. Z. Fang, Flow Injection Separation and Preconcentration, VCH, Weinheim, 1993.

10. M.D. Luque de Castro and M. Valcarcel, Trends Anal. Chem., 5, 71 (1986). 
Vol. XVIII, No. 3 Flow Injection Analysis (FIA) Techniques for the Determination of Inorganics in Molecular and Atomic Spectrometry

11. M. Valcarcel and M.D. Luque de Castro, Anal. Chim. Acta, 250, 157 (1991).

12. M.D. Luque de Castro and M.T. Tena, Talanta, 42, 151 (1995).

13. M.D. Luque de Castro and M. Valcarcel, Lab. Rob. Autom., 3, 199 (1991).

14. M. Valcarcel and M.D. Luque de Castro, Analyst, 118, 593 (1993).

15. M. Valcarcel and M.D. Luque de Castro, Flow-Through (Bio) Chemical Sensors, Elsevier, Amsterdam, 1994.

16. J.F. Tyson, S.R. Bysouth, E.A. Grzeszczyk and E. Debrah, Anal. Chim. Acta, 261, 75 (1992).

17. J.F. Tyson, Anal. Chim. Acta, 234, 3 (1990).

18. L.K. Shpigun, I.Ya Kolotyrkina and Yu.A. Zolotov, Anal. Chim. Acta, 261, 307 (1992).

19. Z. Fang, L. Sun and S. Xu, Anal. Chim. Acta, 261, 557 (1992).

20. D. Chen, M.D. Luque de Castro and M. Valcarcel Analyst, 116, 1095 (1991).

21. M. Valcarcel and M.D. Luque de Castro, Microchem. J., 45, 189 (1992).

22. B. Welz, Microchem. J., 45, 163 (1992).

23. M. Trojanowicz and E. Olbrych-Sleszynska, Chem. Anal., 37, 111 (1992).

24. Z.L. Fang and S.K. Xu, Fenxi Shiyanshi, 12, 97 (1993).

25. Yu.A. Zolotov and L.K. Shpigun, Microchem. J., 45, 225 (1992).

26. J.F. Tyson, Microchem. J., 45, 143 (1992).

27. M. Trojanowicz, Flow Injection Analysis, Instrumentation and Applications, World Scientific Publishing, Singapore, 1996.

28. F.T. Esmadi, I.M. Khasawneh, M.A. Kharoaf and A.S. Attiyat, Anal. Lett., 24, 1231 (1991).

29. A.T. Haj-Hussein, Talanta, 42, 2053 (1995).

30. A.M. Zhang, S.H. Wang, H.S. Wang and H. Cui, Fenxi Huaxue, 25, 37 (1997).

31. B. Fairman and A. Sanz-Medel, Fresenius J. Anal. Chem., 355, 757 (1996).

32. P. Di and D.E. Davey, Talanta, 41, 565 (1994).

33. X. Chen, Y. Xu and Z. Hu, Fenxi Shiyanshi, 9, 283 (1990).

34. L. Kutsera, H. Ghaziaskar and E.P.C. Lai, Anal. Lett., 25, 2289 (1992).

35. W.F. Chan and P.K. Han, Analyst, 115, 567 (1990). 
36. S.A. Huber and F.H. Frimmel, Anal. Chem., 63, 2122 (1991).

37. C.E. Adeeyinwo and J.F. Tyson, Anal. Proc., 26, 375 (1989).

38. N. Chimpalee, D. Chimpalee, R. Jarungpattanaanoan, S. Lawratchavee and D.T. Burns, Anal. Chim. Acta, 271, 247 (1993).

39. H. Shen, L. Lu and J. Yang, Yejin Fenxi, 13, 8 (1993).

40. R.W. Min and E.H. Hansen, Chem. Anal., 40, 361 (1995).

42. D. Chen, R. Cai and Y. Zeng, Lab. Rob. Autom., 7, 133 (1995).

43. W. Li and B. Fu, Fenxi Shiyanshi, 9, 5 (1990).

44. E. Cristofol de Alcaraz, F. Sanchez Rojas and J.M. Cano Pavon, Fresenius J. Anal. Chem., 340, 175 (1991).

45. T. Yamane and K. Koshino, Anal. Chim. Acta, 261, 205 (1992).

46. K. Pyrzynska, Z. Janiszewska, J. Szpunar-Lobinska and M. Trojanowicz, Analyst, 119, 1553 (1994).

47. E. Debrah, C.E. Adeejinwo, S.R. Bysouth and J.F. Tyson, Analyst, 115,1543 (1990).

48. Y. Syama, Y. Hayashibe and M. Takeya, Bunseki Kagaku, 40, 179 (1991).

49. R. Purohit and S. Devi, Talanta, 38, 753 (1991).

50. A.F. Danet and V. Mircea, Rev. Chim., 41, 361 (1990).

52. A.M. Naghmush, M. Trojanowicz, and E. Olbrych-Sleszynska, $J$. Anal. At. Spectrom., 7, 323 (1992).

53. K. Yoshimura, S. Matsuoka, Y. Inokura and U. Hase, Anal. Chim. Acta, 268, 225 (1992).

54. M.A. Menon, X.R. Wang and B.L. Huang, At. Spectrosc., 14, 99 (1993).

55. S. Xu and Z. Fang, Microchem. J., 51, 360 (1995).

56. P. Yu, J.J. Gao and Z.A. Yu, Fenxi Huaxue, 23, 1301 (1995).

57. S. Nakano, K. Nakaso, K. Noguchi and T. Kawashima, Talanta, 44, 765 (1997).

58. J. Chen and Q. Ma, Lihua Jianyan Huaxue, 27, 361 (1991).

59. H. Tabashi, K. Umetsu, K. Satoh and T. Kawashima, Anal. Sci., 7, 163 (1991).

60. S. Li and H.A. Mottola, Anal. Chim. Acta, 289, 79 (1994).

61. S.J. Chalk and J.F. Tyson, Anal. Chem., 66, 660 (1994).

62. K. Toei, S. Hiraishi, T. Nakagawa and M. Zenki, J. Flow Inj. Anal., 10, 94 (1993).

63. G.N. Tang, L.J. Wang and B.N. Wang, Fenxi Huaxue, 23, 1017 (1995). 
Vol. XVIII, No. 3 Flow Injection Analysis (FIA) Techniques for the Determination of Inorganics in Molecular and Atomic Spectrometry

64. Y. Ma, Y. Han and R. Ariguli, Fenxi Huaxue, 22, 586 (1994).

65. B. Hilligsoe, J.E.T. Anderson and E.H. Hanson, J. Anal. At. Spectrom., 12, 585 (1997).

66. S.H. Pia, D.P. Waltman, D.C. Hillman and K.W. Street, Anal. Chim. Acta, 231, 21 (1990).

67. H. Monta, M. Sugimoto and S. Shimomura, Anal. Sci., 6, 91 (1990).

68. M.D. Mateo, R. Forteza and . Cerda, Int. J. Environ. Anal. Chem., 41, 39 (1990).

69. C.P. Hanna, P.E. Haigh, J.F. Tyson and S. McIntosh, J. Anal. At. Spectrom., 8, 585 (1993).

70. W.T. Corns, L.C. Ebdon, S.J. Hill and P.B. Stockwell, J. Autom. Chem., 13, 267 (1991).

71. X. He, Y. Cai and Z. Hu, Fenxi Huaxue, 18, 237 (1990).

72. F.T. Esmadi and M.A. Kharoaf, Can. J. Appl. Spectrosc., 36, 70 (1991).

73. K. Kimura, S. Iketani, H. Sakamoto and T. Shono, Analyst, 115, 1251 (1990)

74. X. Hou, P. Xu and Z. Sun, Guangpuxue Yu Guangpu Fenxi, 10, 38 (1990).

75. D.T. Burns, M. Harriott and P. Pornsinlapatip, Anal. Chim. Acta, 281, 607 (1993).

76. S. Alegret, J. Alonso, J. Bartroli, M. Del Valle, N. Jaffrezic-Renault and Y. Duvault-Herrera, Anal. Chim. Acta, 231, 53 (1990).

77. H. Kuraki, K. Higuchi, M. Sasaki, T. Korenaga and K. Toei, Anal. Chim. Acta, 261, 345 (1992).

78. V.T. Krawczynski and M. Trojanowicz, Anal. Sci., 8, 329 (1992).

79. Y. Lao, R. Al-Othman and G.D. Christian, Talanta, 42, 1545 (1995).

80. Z.L. Zhi, A. Rios and M. Valcarcel, Anal. Chim. Acta, 293, 163 (1994).

81. D. Erber and K. Cammann, Analyst, 120, 2699 (1995).

82. X.S. Chai and L.G. Danielsson, Anal. Chim. Acta, 332, 31 (1996).

83. A.A. Ensafi, Anal. Lett., 29, 1177 (1996).

84. X.G. Chen, H.P. Gong, Q. Zhang and Z.D. Hu, Microchem. J., 52, 364 (1995).

85. B. Welz, M. Sperling and Z. Fang, Fresenius J Anal. Chem., 337, 135 (1990).

86. S.A. Darke, C.J. Pickford and J.F. Tyson, Anal. Proc., 26, 379 (1989). 
137. R.L. Bunde and J.J. Rosentreter, Microchem. J., 47, 148 (1993).

138. J.W. Wang and M. Min, Fenxi Huaxue, 24, 798 (1996).

139. E. Miralles, D. Pratt, R. Compano and M. Grandos, Analyst, 122, 553 (1997).

140. A.T. Haj-Hussein, Talanta, 44, 545 (1997).

141. V.I. Shlyamin, O.N. Obrezkov, O.A. Shpigun and Yu.A. Zolotov, Zh. Anal. Khim., 46, 76 (1991).

142. J. Wei, F. Lin and X. Wang, Fenxi Huaxue, 18, 995 (1990).

143. J. Alonso-Chamarro, J. Bartroli and R. Barber, Anal. Chim. Acta, 261, 219 (1992).

144. O. Egorov and J. Ruzicka, Analyst, 120, 1959 (1995).

145. F.J. Andrade, M.B. Tudino and O.E. Troccoli, Analyst, 121, 613 (1996).

146. M.F. Grigoreva, Yu.G. Murzina and A.V. Kalyamin, Zh. Anal. Khim., 51, 1042 (1996).

147. M.S. Jimenez, L. Martin, J.M. Mir and J.R. Castillo, At. Spectrosc, 17, 201 (1996).

148. T. Prasada Rao, S. Kartikeyan, B. Vijayalekshmy and C.S.P. Iyer, Anal. Chim. Acta, 369, 69 (1998).

149. I. Aoki, M. Tuyuki and K. Watanabe, Bull. Chem. Soc. Japan, 65, 911 (1992).

150. N. Yonehara, S. Chaen, K. Matsumoto, T. Tomiyasu and H. Sakamoto, J. Flow Inj. Anal., 13, 35 (1996).

151. P. Wang and S.J. Shi, Fenxi Huaxue, 24, 720 (1996).

152. C.K. Chandrawanshi, S.K. Chandrawanshi and K.S. Patel, J. Autom. Chem., 18, 181 (1996).

153. S. Xu, L. Sun and Z. Fang, Fenxi Shiyanshi, 11, 16 (1992).

154. H.N. Wang and F.Q. Shang, Fenxi Huaxue, 24, 288 (1996).

155. Y. Chen, X. Zhao, Z. Kou and Z. Hu, Mikrochim. Acta, 1991 I (5-6), 279.

156. D.T. Burns, S.A. Barakat, M. Harriott and M.S. El-Shahawi, Anal. Chim. Acta, 270, 213 (1992).

157. D.T. Burns, S.A. Barakat, M.S. El-Shahawi and M. Harriott, Fresenius J. Anal. Chem., 344, 131 (1992).

158. S. Nakano, M. Nozawa, M. Yanagawa and T. Kawashima, Anal. Chim. Acta, 261, 183 (1992).

159. X.Z. Chi and J. Zhou, Guangpuxue Yu Guangpu Fenxi, 14, 91 (1994). 
Vol. XVIII, No. 3 Flow Injection Analysis (FIA) Techniques for the Determination of Inorganics in Molecular and Atomic Spectrometry

160. C.S.P. Iyer, T. Prasada Rao, S. Kartikeyan and A.D. Damodaran, $A t$. Spectrosc., 15, 234 (1994).

161. A.G. Shirinova, T.V. Rodionova, V.M. Ivanov, M.K. Berklemishev and Yu.A. Zolotov, Zh. Anal. Khim., 48, 55 (1993).

162. G. Zhang, S. Liu, X. He and H. Shi, Gaodeng Xuexiao Huaxue Xuebao, 14, 492 (1993).

163. A. Chaurasia and K.K. Verma, Talanta, 41, 1275 (1994).

164. X.G. Chen, K.T. Wang, Z.D. Hun and Z. Zhao, Anal. Lett., 29, 2015 (1996).

165. N. Lacy, G.D. Christian and J. Ruzicka, Quim. Anal, 8, 201 (1989).

166. G. Song, Guangpuxue Yu Guangpu Fenxi, 11, 59 (1991).

167. R. Vonach, B. Lendl and R. Kellner, Analyst, 122, 525 (1997).

168. F.S. Sun and T. Korenaga, Appl. Spectrosc., 50, 1145 (1996).

169. H. Koshima and H. Onishi, Anal. Chim. Acta, 232, 287 (1990).

170. M. Yaqoob, M. Anwar, A.S. Masood and M. Masoom, Anal. Lett., 24, 581 (1991).

171. A.A. Ensafi, Anal. Lett, 25, 1525 (1992).

172. H.H. Xu and J.H. Chen, Fenxi Huaxue, 20, 844 (1992).

173. E. Aoyama, K. Akamatsu, T. Nakagawa and H. Tanaka, Anal. Sci., 7, 617 (1991).

174. W. Qi and X. Chen, Fenxi Huaxue, 19, 433 (1991).

175. S.G. Offley, N.J. Seare, J.F. Tyson and H.A.B. Kibble, Anal. Proc., 28, 18 (1991).

176. M.G. Cobo Fernandez, M.A. Palacios and C. Camara, Anal. Chim. Acla, 283, 386 (1993).

177. E.H. Hansen, Egypt. J. Anal. Chem., 3, 68 (1994).

178. S. Nielson, J.J. Sloth and E.H. Hansen, Analyst, 121, 31 (1996).

179. R.M. Olivas, C.R. Quetel and O.F.X. Donard, J. Anal. At. Spectrom., 10, 865 (1995).

180. A.A. Ensafi, Ind. J. Chem., 36A, 105 (1997).

181. F. Mas, J.M. Estela and V. Cerda, Anal. Chim. Acta, 239, 151 (1990).

182. T. Miyaji and K. Hibi, J. Flow Inj. Anal., 6, 151 (1989).

183. J.S. Cosano, M.D. Luque de Castro and M. Valcarcel, Anal. Chim. Acta, 302, 269 (1995).

184. A.E. Davies and A.G. Fogg, Anal. Chim. Acta, 318, 55 (1995).

185. A. Safavi and B. Haghighi, Talanta, 44, 1009 (1997).

186. A.G. Fogg, X. Wang and J.F. Tyson, Analyst, 115, 305 (1990). 
187. K.J. Wang, Fenxi Shiyanshi, 11, 40 (1992).

188. B. Haghighi, N. Maleki, A. Massoumi, S. Razi and A. Safavi, Microchem. J., 42, 319 (1990).

189. N. Teshima, H. Itabashi and T. Kawashima, Chem. Lett, 11, 2227 (1992).

190. N. Teshima, H. Itabashi and T. Kawashima, Anal. Sci, 10, 207 (1994).

191. S.H. Wang, A.M. Zhang, L.Y. Du, C.L. Ma and D.J. Liu, Fenxi Huaxue, 24, 832 (1996).

192. I.M. Maksimova, D.N. Korolev, L.I. Morosanova and Yu.A. Zolotov, Zh. Anal. Khim., 50, 919 (1995).

193. Yu.A. Zolotov, E.I. Morosanova, S.V. Zhalovannaya and S,.S. Dyukarev, Anal. Chim. Acta, 308, 386 (1995).

194. M.C. Brennan and G. Svehla, Fresenius' J. Anal. Chem., 335, 893 (1989).

195. T. Yamane and E. Goto, Talanta, 38, 139 (1991).

196. S. Caroli, A. Alimonti, F. Petrucci and Z. Horvach, Anal. Chim. Acta, 248, 241 (1991).

197. K.R. Brushwyler, L.D. Carter and G.M. Hieftje, Appl. Spectrosc., 44, 1438 (1990).

198. F.T. Esmadi, I.M. Khasawneh, M.M. Kharoaf and A.S. Attiyat, Can. J. Appl. Spectrosco., 37, 119 (1992).

199. E.H. Larsen and J.S. Blaise, J. Anal. At. Spectrom., 8, 659 (1993).

200. Z. Zhang and X. Zeng, Guangpuxue Yu Guangpu Fenxi, 11, 32 (1991).

201. S. Xu, L. Sun and Z. Fang, Talanta, 39, 581 (1992).

202. B. Welz, X. Yui and M. Sperling, Anal. Chim. Acta, 261, 477 (1992).

203. D.M. Ye, H.Q. Zhang and Q.H. Jin, Talanta, 43, 535 (1996).

204. R. Ma and F.C. Adams, Spectrochim. Acta, 51B, 1917 (1996).

205. E.V. Kirko, N.M. Sorokina, N.N. Galdona, G.I. Tsizin and Yu.A. Zolotov, Zavod Lab., 62, 26 (1996).

206. F. Sanchez Rojas, E. Cristofol de Alcaraz and J.M. Cano Pavon, J. Flow Inj. Anal., 10, 56 (1993).

207. S. Devi, K.A.J. Habib and A. Townshend, Quim. Anal., 8, 159 (1989). 
Vol. XVIII, No. 3 Flow Injection Analysis (FIA) Techniques for the Determination of Inorganics in Molecular and Atomic Spectrometry

208. P. Richter, M.I. Toral and P. Hernandez, Anal. Lett., 29, 1013 (1996).

209. S. Kartikeyan, B. Vijayalekshmy, T. Prasada Rao and C.S.P. lyer, Anal. Lett., 30, 1037 (1997).

210. H.P. Huang and S.L. Liu, Fenxi Shiyanshi, 13, 73 (1994).

211. Y. Li and Y. Narusawa, Bunseki Kagaku, 41, 463 (1992).

212. S.L. Liu and H.P. Huang, Talanta, 40, 1077 (1993).

213. X.J. Peng, Z.C. Jiang and Y. Zeng, Fenxi Shiyanshi, 13, 39 (1994).

214. T. Prasada Rao, K.A. Tony, S. Kartikeyan and C.S.P. Iyer, Analyst, 124, 191 (1999).

215. S. Kozuka, K.A. Saito, K. Oguma and R. Kuroda, Analyst, 115, 431 (1990).

216. T. Kitamura, K. Koshino and T. Yamane, Bunseki Kagaku, 41, 101 (1992).

217. K. Oguma, S. Kozuka, Kitada and R. Kuroda, Fresenius J. Anal. Chem., 341, 545 (1991).

218. J.H. Wang and R.H. He, Anal. Chim. Acta, 276, 419 (1993).

219. J.H. Wang, W.J. Ruan and R.H. He, Fenxi Huaxue, 21, 593 (1993).

220. D. Chen, Y. Zhong and S. Liang, Fenxi Ceshi Tongbao, 24, 1166 (1996).

221. J.H. Wang and R.H. He, Anal. Chim. Acta, 294, 195 (1994).

222. D. Chen, Y. Zhong and S. Liang, Fenxi Ceshi Tongbao, 9, 1 (1990).

223. M. Aihara and T. Nakashimada, J. Flow Inj. Anal., 6, 128 (1989).

224. B. Moreno Cordero and J.L. Perez Pavon, Anal. Chim. Acta, 234, 239 (1990).

225. Q. Shen, Z. Jiang and Z. Liao, Fenxi Shiyanshi, 10, 45 (1991).

226. J. Havel, C. Moreno, A. Hrdlicka and M. Valiente, Talanta, 41, 1251 (1994).

227. J. Fu, G. Lin, J. Yang, Z. Wang and C. Ma, Huaxue Tongbao, 8, 48 (1990).

228. T. Yokoyama, T. Watarai, T. Uehara, K. Muzuoka, K. Kohara, M. Kido and M. Zenki, Fresenius J. Anal. Chem., 357, 860 (1992).

229. S. Greenfield, T.M. Durrani, S. Kaya and J.F. Tyson, Analyst, 115, 531 (1990). 
230. T. Perez-Ruiz, C. Martinek-Cozano, V. Tomas and C. Paredes, Mikrochim. Acta, 118, 203 (1995).

231. R.M. Liu, D.J. Liu, A.L. Sun and G.H. Liu, Analyst, 120, 565 (1995).

232. R.H. He, J.H. Wang and Y.B. Wang, Fenxi Huaxue, 24, 274 (1996).

233. K. Yoshida and S. Motomizu, Bunseki Kagaku, 40, T110 (1991).

234. T. Guo, J. Baasner and S. McIntosh, Anal. Chim. Acta, 331, 263 (1996).

235. R. Ma and F. Adams, Anal. Chim. Acta, 317, 219 (1995).

236. X.J. Qui, J. Zhou and H.Z. Yin, Fenxi Huaxue, 25, 168 (1997).

237. G.Y. Zhang, Q.S. Huang, D.S. Mao and T.Y. Chen, Fenxi Huaxue, 21, 63 (1993).

238. T. Yamane and Y. Yamaguchi, Anal. Chim. Acta, 345, 139 (1997).

239. L.K. Shpigun and Zh. Gureva, Zh. Anal. Khim., 46, 2187 (1991).

240. Z. Peng, H. Klinkenberg, T. Beeren and W. Van Born, Spectrochim. Acta, 46B, 1051 (1991).

241. K.R. Koch and D. Auer, Talanta, 40, 1975 (1993).

242. Y.J. Xu, X.G. Chen and Z.D. Hu, Anal. Chim. Acta, 292, 191 (1994).

243. J.H. Wang, R.H. He and Y.H. Tong, Chem. Anal, 41, 577 (1996).

244. T. Mochizuki, A. Sakashita, H. Iwata, Y. Ishibashi and N. Gunji, Anal. Sci., 6, 191 (1990).

245. P. Van De Weijer, P.G.M.G. Vullings, W.L.M. Baeten and W.J.M. De Laat, J. Anal. At. Spectrom., 6, 609 (1991).

246. J.H. Wang and R.H. He, J. Radioanal. Nucl. Chem., 176, 117 (1993).

247. A.M. Almuaibed and A. Townshend, Fresenius' $Z$. Anal. Chem., 335, 905 (1989).

248. R. Purohit and S. Devi, Analyst, 116, 825 (1991).

249. N. Porter, B.T. Hart, R. Morrison and I.C. Hamilton, Anal. Chim. Acta, 281, 229 (1993).

250. M. Sperling, P. Koscielnik and B. Welz, Anal. Chim. Acta, 261, 115 (1992).

251. B. Qi and X.M. Chen, Fenxi Shiyanshi, 11, 27 (1992).

252. X.W. Guo and X.M. Guo, Guangpuxue Yu Guangpu Fenxi, 15, 97 (1995). 
Vol. XVIII, No. 3 Flow Injection Analysis (FIA) Techniques for the Determination of Inorganics in Molecular and Atomic Spectrometry

253. H. Klinkenberg, T. Beeren and W. Van Born, Spectrochim. Acta, 49B, 171 (1994).

254. M.C. Brennan, R.A. Simons, G. Svehla and P.B. Stockwell, J. Autom. Chem., 12, 183 (1990).

255. G.D. Marshall and J.F. Vanstaden, J. Anal. At. Spectrom., 5, 681 (1990).

256. E. Liu, W.J. Chen and C.Y. Zhao, Fenxi Huaxue, 21, 328 (1993).

257. Y.P. Ma, Fenxi Shiyanshi, 12, 87 (1993).

258. T. Guo, M. Liu and W. Schrader, J. Anal. At. Spectrom., 7, 667 (1992).

259. H.N. Wang, Y. Chen and J. Wang, Anal. Proc., 31, 357 (1994).

260. R. Siska, J. Borszeki and E. Gegus, Magy. Kem. Foby., 63, 248 (1996).

261. R. Siska, J. Borszeki and E. Gegus, Can. J. Applied Spectrosc., 40, 117 (1995).

262. A.M. Almuaibed and A. Townshend, Anal. Chim. Acta, 245, 115 (1991).

263. F.T. Esmadi, M.A. Kharoaf and A.S. Attiyat, Talanta, 37, 1123 (1990).

264. F. Camuna, J.E. Sanchez-Uria and A. Sanz-Medel, Spectrochim. Acta, 48, 1115 (1993).

265. A. Chaurasia and K.K. Verma, Fresenius J. Anal. Chem., 351, 335 (1995).

266. A. Tanaka, K. Deguchi and T. Deguchi, Anal. Chim. Acta, 261, 281 (1992).

267. F.T. Esmadi, M. Kharoaf and A.S. Attiyat, J. Flow Inj. Anal., 10, 33 (1993).

268. H.C. Ma, J.F. Liu, J.Z. Feng and Y. Gao, J. Flow Inj. Anal., 11, 58 (1994).

269. F.T. Esmadi and A.S. Attiyat, Anal. Sci., 10, 687 (1994).

270. I.A. Gurev, L.F. Zyuzina and O.P. Lazareva, Zh. Anal. Khim., 49, 579 (1994). 
271. M. Yaqoob, M. Masoom and A. Townshend, Anal. Chim. Acta, 248, 219 (1991).

272. R.M. Liu, G.H. Liu, D.J. Liu and A.L. Sun, Fenxi Huaxue, 23, 407 (1995).

273. M.J. Ahmed, C.D. Stalikas, S.M. Tzouwara-Karayanni and M.I. Karayannis, Talanta, 43, 1009 (1996).

274. M.T. Oms, A. Cerda and V. Cerda, Anal. Chim. Acta, 315, 321 (1995).

275. U. Voellkopf, A. Guensel and A. Janssen, Atm Spectrosc., 11, 135 (1990).

276. H. Zhang, H. Pan and W. Cheng, Fenxi Shiyanshi, 9, 31 (1990).

277. F. Mas, J.M. Estela and V. Cerda, Int. J. Environ. Anal. Chem., 43, 71 (1991).

278. T. Prasada Rao, M.L.P. Reddy and A.R. Pillai, Talanta, 46, 765 (1998). 
